\title{
Advances and Challenges of Biodegradable Implant Materials with a Focus on Magnesium-Alloys and Bacterial Infections
}

\author{
Muhammad Imran Rahim ${ }^{1}$, Sami Ullah ${ }^{2}$ and Peter P. Mueller ${ }^{3, *}$ (i) \\ 1 Department of Prosthetic Dentistry and Biomedical Materials Science, Lower Saxony Centre for Biomedical \\ Engineering, Implant Research and Development, Hannover Medical School, Carl-Neuberg-Straße 1, \\ 30625 Hannover, Germany; M.Imran.Rahim@outlook.com \\ 2 Department of MSYS, Helmholtz Center for Infection Research, Inhoffenstrasse 7, \\ 38124 Braunschweig, Germany; Sami.Ullah@helmholtz-hzi.de \\ 3 Department of Chemical Biology, Helmholtz Center for Infection Research, Inhoffenstrasse 7, \\ 38124 Braunschweig, Germany \\ * Correspondence: pmu@gbf.de; Tel.: +49-531-6181-5070
}

Received: 12 June 2018; Accepted: 4 July 2018; Published: 10 July 2018

\begin{abstract}
Medical implants made of biodegradable materials could be advantageous for temporary applications, such as mechanical support during bone-healing or as vascular stents to keep blood vessels open. After completion of the healing process, the implant would disappear, avoiding long-term side effects or the need for surgical removal. Various corrodible metal alloys based on magnesium, iron or zinc have been proposed as sturdier and potentially less inflammatory alternatives to degradable organic polymers, in particular for load-bearing applications. Despite the recent introduction of magnesium-based screws, the remaining hurdles to routine clinical applications are still challenging. These include limitations such as mechanical material characteristics or unsuitable corrosion characteristics. In this article, the salient features and clinical prospects of currently-investigated biodegradable implant materials are summarized, with a main focus on magnesium alloys. A mechanism of action for the stimulation of bone growth due to the exertion of mechanical force by magnesium corrosion products is discussed. To explain divergent in vitro and in vivo effects of magnesium, a novel model for bacterial biofilm infections is proposed which predicts crucial consequences for antibacterial implant strategies.
\end{abstract}

Keywords: bioresorbable implants; corrosion layer; vascular stents; orthopedic implants; microbial infections

\section{Introduction}

For metallic implants, industrially-developed, inert and long-lasting materials, such as titanium (Ti) alloys, stainless steel (SS) and cobalt-chromium (CoCr) alloys, are most frequently used [1-4]. The duration of the healing process is highly variable depending on the extent of injury, disease state, age and treatment. In general, healing time may range from a brief one month period, up to a six month period in more complex cases. Permanent implants are frequently removed after the completion of the healing process to avoid diverse side effects. Long-term disadvantages of this practice include the failure to adapt to rapid growth in young children, bone degradation by stress shielding, microbial implant infections, excessive fibrosis or persistent inflammation. Novel bioresorbable metal implants could provide support during the healing process, and then disappear to avoid long-term side effects without requiring surgical removal [5,6]. Conventionally, initial material tests are done most economically in vitro under precisely defined technical conditions. Subsequent assays 
are performed under increasingly complex and more costly cell culture conditions, followed by small animal experiments and eventually tested in large animals or in clinical trials. However, corrosion results obtained under simple technical conditions cannot be extrapolated to clinical circumstances. In one study, the corrosion rate for magnesium alloys was reported to differ four orders of magnitude between in vitro and in vivo conditions [7]. Due to inherent limitations in reproducing the complexities of living tissue in vitro, this review preferentially refers to animal models or clinical trials if available [8,9]. For molecular genetic and economic reasons, small animal studies are most popular. However, for load bearing applications in particular, size is an important parameter that must be kept in mind, and eventually large animal experiments and clinical data are essential. Even though intense research efforts recently culminated in clinical reports, degradable metallic implants are not yet routinely applied (see Section 7 for details). Compared to organic polymers, biodegradable metals can achieve higher strengths and ductility and would therefore would be preferential for load bearing applications such as bone plates, screws or coronary stents [10]. Three types of metal alloys have been commonly-investigated as degradable implants for biomedical applications based on magnesium, iron or zinc. The main purpose of this article is a brief and easily understandable overview of virtues and clinical hurdles of self-degrading implants as screws, plates or intramedullary rods for load-bearing orthopedic (musculoskeletal) applications or as vascular stents. In addition, a novel model for implant infections is proposed to explain divergent effects of magnesium on bacteria in vitro and in vivo.

\section{Material Requirements for Fully-Bioresorbable Vascular Stents}

Clinical requirements provide the basis for the required implant material characteristics. Age-related vascular malfunctions such as vessels clogged by a blood clot are of growing importance [11,12]. One of the earliest effective treatments was antithrombotic therapy, but this required some time until the clot was dissolved. Then, vascular stents, used to keep blood vessels open, were shown to be superior, despite the fact that treatment had to be delayed to prevent patient deaths. Balloon angioplasty is routinely applied and requires minimal invasive surgery. A small folded stent on a balloon at the tip of a catheter is maneuvered through blood vessels until it is located at the site of the restriction. The position within the body can be monitored with the help of an X-ray camera. For this reason, an X-ray dense stent material is an advantage. Once positioned, the balloon is inflated to unfold the stent. Stents are overextended to a limited degree to allow a firm anchoring in the vessel wall to prevent migration, and to compensate for the inherent elastic recoil of the stent after the balloon had deflated. The stent material must be sturdy enough to allow for thin struts, minimize the recoil, and withstand the pressure of the tissue and the forces during movements of the body [13]. It is clinically well established that thin, yet robust and highly ductile, stainless steel or shape memory alloy stents fulfill these requirements. Nevertheless, initial stent overextension and subsequent persistent mechanical stress, due to interactions with pulsing blood vessel walls, stimulates smooth muscle cell proliferation in the vessel walls. In a process, termed restenosis, a growing mass of proliferating vascular smooth muscle-related cells eventually obstruct the stented vessel again. The blood flow may be reestablished by inserting a second stent or through surgical bypass, leading to additional patient discomfort, risks and costs [14,15]. In clinical applications restenosis has been successfully curbed by drug-eluting stents [16]. Thereby, unwanted cell growth is suppressed locally by clinically well-established drug-loaded polymer coated stents that gradually release immune suppressive agents like sirolimus or the antiproliferative-acting drug paclitaxel. Even though these drugs could reduce the incidence of restenosis, serious side effects include a delayed healing response, inflammation and persistent thrombosis risks [17-20]. This results in the requirement of costly regular and prolonged antiplatelet treatments, and non-complying patients drastically increase the thrombosis hazard [21]. Therefore, the application of drug-eluting stents must be carefully considered for each patient individually depending on the restenosis risks and the treatment-associated bleeding vulnerability. As an alternative, long-term side effects could be avoided by using fully biodegradable stents which provide the essential support for a few weeks during the 
healing process, and then completely disappear [22-25]. Key degradable stent material requirements are appropriate corrosion characteristics, biocompatibility, high elasticity to allow for small folded stents and sufficient strength to resist collapsing.

\section{Material Requirements for Degradable Orthopedic Implants}

To allow healing, broken bones must be firmly stabilized to avoid even micro-movements under the influence of considerable forces. Since inflammation may antagonize bone repair, the implant must be highly biocompatible. Clinically, all requirements are met by sturdy plates, screws or intramedullary nails made of titanium alloys or stainless steel. Nevertheless, after completion of the healing process stress shielding implants are mostly removed since their prolonged presence can lead to bone degradation [26]. Strong, tissue friendly self-degrading implants with bone-like mechanical parameters, to minimize stress-shielding, and suitable degradation characteristics could reduce such side effects. Furthermore, they allow patients to avoid a second surgery for implant removal, making them a highly attractive option. Whereas conventional permanent implant materials are sturdy and biologically inert, resorbable polymeric materials, as well as corrodible metals, have distinct biological characteristics (Table 1). In the following table, the cardinal properties of the most intensively investigated prospective biodegradable implant materials for load-bearing applications are described.

Table 1. Basic properties of degradable implant materials.

\begin{tabular}{|c|c|c|c|c|}
\hline $\begin{array}{l}\text { Implant } \\
\text { Material }\end{array}$ & Degradation Speed & $\begin{array}{l}\text { Physical and Corrosion } \\
\text { Characteristics }\end{array}$ & Biological Effects & References \\
\hline $\begin{array}{l}\text { Organic } \\
\text { polymers }\end{array}$ & Adjustable & $\begin{array}{l}\text { Potentially flexible but mostly } \\
\text { too weak for load-bearing } \\
\text { applications; Implant swelling } \\
\text { in moist environments; X-ray } \\
\text { transparent }\end{array}$ & $\begin{array}{l}\text { Inflammatory acidic } \\
\text { hydrolysis products }\end{array}$ & {$[27,28]$} \\
\hline Iron & $\begin{array}{c}\text { Very slow, complete } \\
\text { degradation may require } \\
\text { several years }\end{array}$ & $\begin{array}{l}\text { Sturdy but irregular corrosion } \\
\text { characteristics }\end{array}$ & $\begin{array}{l}\text { Accumulation of } \\
\text { inflammatory iron } \\
\text { hydroxide particles in } \\
\text { various tissues }\end{array}$ & [29-31] \\
\hline Zinc-based & $\begin{array}{l}\text { Slow, life-time by far } \\
\text { exceeds expected } \\
\text { healing periods }\end{array}$ & Suboptimal strength & Non-inflammatory & {$[32,33]$} \\
\hline Magnesium-based & $\begin{array}{l}\text { Rapid, danger of } \\
\text { mechanical implant } \\
\text { failure before the healing } \\
\text { process is completed }\end{array}$ & $\begin{array}{l}\text { Alloys with sufficient strength } \\
\text { available; compliance can be } \\
\text { adjusted; irregular pitting } \\
\text { corrosion; corrosion coat } \\
\text { formation due to slowly } \\
\text { dissolving solid precipitates } \\
\text { resulting in reduction of initial } \\
\text { corrosion rates }\end{array}$ & $\begin{array}{l}\text { Non-inflammatory; gas } \\
\text { accumulation in the } \\
\text { tissue; accumulating } \\
\text { solid corrosion products } \\
\text { or gaseous hydrogen } \\
\text { may exert pressure on } \\
\text { non-yielding bony tissue }\end{array}$ & [34-36] \\
\hline Surgical steel & inert & $\begin{array}{l}\text { Sturdy, suitable for } \\
\text { load-bearing applications, } \\
\text { allows for ductile thin } \\
\text { vascular stent struts }\end{array}$ & Non-inflammatory, inert & [1] \\
\hline Titanium & inert & $\begin{array}{l}\text { Sturdy, highly suitable for } \\
\text { load-bearing applications }\end{array}$ & $\begin{array}{l}\text { Non-inflammatory, } \\
\text { bone-friendly surface } \\
\text { oxide layer }\end{array}$ & [1] \\
\hline
\end{tabular}

\section{Polymeric Vascular Stents}

Even though they may act somewhat inflammatory compared to metals, biodegradable polymeric implants have been routinely employed as suture material and to temporarily fix tendons to bones until they eventually adhere by themselves [37,38]. Popular hydrolysable polymers used for bioresorbable scaffolds are poly(lactic-co-glycolic) acid (PLGA), polylactic acid (PLA) or polyglycolic acid (PGA) [39]. A main research focus has been polymeric stents, resulting in data that revealed several features that 
had to be optimized. Since polymeric materials are generally less sturdy than metals, thicker struts are required. This results in stents that are more difficult to direct through small vessels. Moreover, they are X-ray transparent and therefore harder to localize in the patient. Polymers also tend to swell in aqueous environments and acidic hydrolysis products can act inflammatory [27]. In experimental animal models degrading polymer stents resulted in increased restenosis rates [40,41]. One of the first commercially available fully absorbable polylactic acid stent (Absorb, Abbot) that was FDA approved in 2016 dissolved in two to three years, but despite promising short-term results long-term side effects were negative and sales were terminated by 2017 [42,43]. In clinical trials these polymer stents were more difficult to insert due to the increased efforts required for imaging, and over a two-year period induced higher rates of in-stent thrombosis than drug eluting metal stents [44]. In summary, the presently investigated resorbable polymer stents were deemed inferior to established metal stents.

\section{Iron as a Prospective Stent Material}

Pure iron and iron alloys were proposed in 2001 for corrodible stent materials [45]. Despite appropriate mechanical properties, iron implants take years to disappear. The corrosion rate is an order of magnitude too small for the implant to disappear without long-term side effects $[30,46,47]$. The immediate oxidation products $\left(\mathrm{Fe}^{2+}\right)$ and ferrous $\left(\mathrm{Fe}^{3+}\right)$ ions are essential for life and presumably non-toxic at the expected concentrations [48-52]. In pioneering animal experiments iron implants analysis revealed insoluble iron hydroxide precipitates that accumulated mainly at the site of implantation [45,53]. Further analyses, in a mouse model, revealed iron precipitates engulfed by local cells. After a few weeks these iron laden cells could be detected in various organs throughout the body [54]. In war veterans, corroding iron fragments from grenade splinters have been shown to migrate in the body and to cause chronic inflammation [55-57]. Overall, the slow degradation rate prolonged possible side effects after completion of the healing process, and inflammatory precipitates impede clinical applications of iron implants.

\section{Zinc Alloy Stents}

Corrodible zinc-based implants have been introduced relatively recently in 2013 (reviewed in [58]). Even though the mechanical properties can be adjusted according to the requirements, zinc alloys, with a reported yield strength up to $300 \mathrm{MPa}$, are not as strong as titanium or stainless steel [59]. When tested, zinc alloys corroded with favorable kinetics, faster than iron, but less rapidly than magnesium alloys. Zinc alloy degradation products were considered sufficiently biocompatible [60]. In a rat model, zinc stents were still structurally intact after four months in the abdominal aorta. The implant and the relevant degradation product $\mathrm{Zn}^{2+}$ appeared non-toxic and even anti-inflammatory [61]. One year after the implantation of a pure zinc stent in a rabbit aorta, an examination revealed artery remodeling and tissue healing without signs of inflammation, platelet aggregation or thrombosis [33]. It was therefore concluded that selected zinc alloys had promising strength and excellent biocompatibility for prospective bio-corrodible stent applications [62]. Nevertheless, it remains to be demonstrated in clinical trials that zinc alloys provide advantages over clinically established permanent metal alloys.

\section{Characteristics of Magnesium-Based Implants}

The first reported medical application of degradable magnesium alloys in humans, as ligature wire, was investigated in 1878 [63]. Side effects included the occurrence of gas pockets in the tissue, and rapid, irregular pitting corrosion leading to premature implant failure. In part, pure magnesium has been experimentally used to simplify the interpretation of biological responses. In general, alloy metals such as aluminum, calcium, lithium, zirconium and rare earth elements have been used to adjust mechanical properties such as the same stiffness as bony tissue or to reduce the degradation rate. In addition, grain refinement, protective surface coatings, and metallic glasses obtained by ultrafast 
cooling techniques resulted in improved degradation characteristics, increased material strength and bone-compatible elastic moduli [64-75].

In biological environments magnesium reacts with water molecules in a pitting type corrosion with kinetics that depend on the surrounding tissue [76-78]. In addition, irregular corrosion could lead to premature mechanical implant failure $[79,80]$. The primary magnesium corrosion products-soluble magnesium ions $\left(\mathrm{Mg}^{2+}\right)$, hydroxide ions $\left(\mathrm{OH}^{-}\right)$, and hydrogen gas $\left(\mathrm{H}_{2}\right)$-are well tolerated by the body. $\mathrm{Mg}^{2+}$ ions are essential for living cells, by complexing with the energy carrier adenosine triphosphate and numerous enzymatic processes, and excess $\mathrm{Mg}^{2+}$ can be excreted in the urine $[81,82]$. Soluble hydroxide ions could in principle lead to toxic $\mathrm{pH}$ increases [76]. However, in biological environments magnesium implants appear highly biocompatible presumably due to an adequate buffering capacity of the tissue. In addition, magnesium and hydroxide ions combine in a $\mathrm{pH}$ neutral way, and, together with carbonic acid, phosphates and other components present in surrounding body fluids, precipitate to form a corrosion-retarding and highly biocompatible implant-tissue interface $[83,84]$. However, perhaps initially surprisingly, during corrosion these precipitates can transiently lead to increases of the overall implant mass and volume. This is particularly critical for implants in non-yielding bony tissue. Stimulation of new bone growth and calcium phosphate deposition has also been observed. This may be due to magnesium hydroxide deposition, calcium phosphate precipitation at the tissue interface and the exertion of mechanical stress by the resulting volume increase [85-87]. One gram of $\mathrm{Mg}$ can generate around one liter of hydrogen gas. Hydrogen gas is non-toxic and easily diffusible, but excessive corrosion can nevertheless lead to formation of undesirable gas bubbles (emphysema) in surrounding soft tissue. Excessive corrosion may also lead to a buildup of pressure in bone enclosed cavities and may, therefore, stimulate bone growth in appropriate setups $[88,89]$.

In orthopedic applications selected magnesium alloys could achieve mechanical properties more similar to human bone than titanium or steel. This could be favorable as it would reduce implant-associated stress shielding and bone degradation [90,91]. Magnesium-based screws have been used in bone healing clinical trials without notable side effects reported by patients $[92,93]$. The first commercial magnesium screws (Magnezix, Syntellix, Hannover, Germany) were available in 2013, and completely disappeared one to two years after implantation [94]. Furthermore, recently an additional interference screw, made of an MgYREZr-alloy, has been introduced to the market (Milagro; DePuy Mitek, Leeds, United Kingdom) [95]. A transient appearance of radio translucent areas around magnesium implants was reported [96]. In fact, such a phenomenon would be expected from the above proposed mechanism; an initial magnesium implant size expansion by the deposition and the subsequent resorption of solid corrosion products, leaving a temporary void space to be filled by bony tissue.

Vascular magnesium alloy stents with reduced corrosion rates have been shown to be mechanically stable for up to 6 months in animal experiments and were eventually evaluated in clinical trials [97-103]. Polymer-coated drug-eluting magnesium stents (Magmaris and DREAMS; Biotronik AG, 231, Bülach, Switzerland) were commercially offered and claimed to be resorbed to $95 \%$ within a year in clinical trials. Thus, they may thereby overcome long-term side effects [104-106]. Both orthopedic and vascular magnesium implants appear promising but, with the exception of small orthopedic implants like pins or screws, the development of these options is still in its infancy, and a broader clinical applicability needs to be demonstrated [107].

\section{Magnesium Implant Infection Susceptibility Mechanism: Race for the Surface versus Susceptible Tissue Surface Model}

Bacterial implant infections are difficult problem to treat in orthopedics, particularly in non-sterile environments like the oral cavity [108]. Bacteria can form recalcitrant biofilms on implant surfaces that are resistant to conventional antibiotic treatments. As a last resort, the entire implant may have to be removed to allow an efficacious antibiotic treatment before the implant can be replaced. Corroding 
magnesium has been shown to act as an antibacterial in vitro due to the generation of hydroxide ions and $\mathrm{pH}$ increases [109-112]. In animal studies, an enhanced susceptibility to bacterial infections has been observed [113,114]. The reasons that could enhance the susceptibility to infection in vivo are not understood, and difficult to explain. Any model must take into account that the corrosion effects are no different in vitro, where there is no such enhanced susceptibility. The proposed model is an attempt to explain this observation. Conventionally, exposed implant surfaces are thought to be susceptible to bacterial adherence in competition with host tissue adhesion [115]. To allow bacterial adhesion and survival on the freshly implanted magnesium, toxic $\mathrm{pH}$ increases directly at the interface would have to be prevented in vivo. Unfortunately, experimental observation of the initial steps of bacterial invasion has not been accomplished so far. However, this scenario appears unlikely if a freshly implanted magnesium surface does act bactericidal. Importantly, despite systemic antibiotic treatment, bacterial biofilms on magnesium were observed. Not only were they observed on the implant surface but, also in the adjacent tissue (Figure 1), suggesting that bacterial adhesion to the implant may actually not be essential for biofilm formation [113].

Alternatively, similar to burn wound infections or keratitis, initial bacterial invasion could occur via the wound liquid to susceptible wounded tissue surfaces (Figure 2) [116,117]. If true for implanted materials other than magnesium, this scenario would predict dire consequences for implant infection prevention strategies.

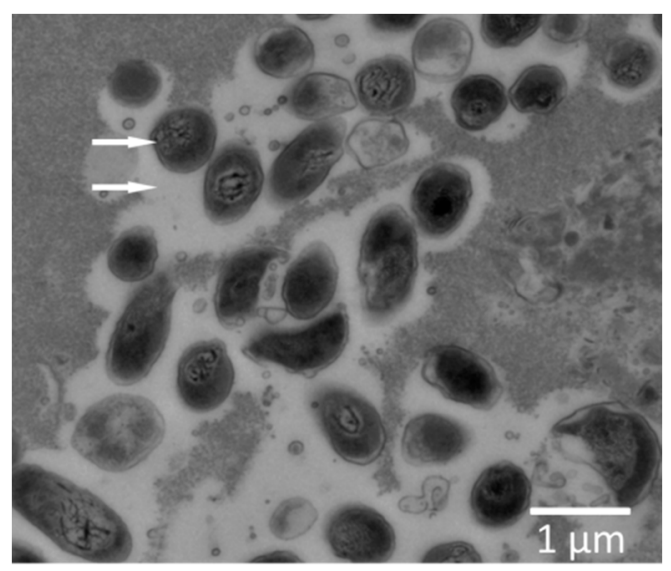

Figure 1. Bacterial biofilm in tissue pockets at a distance from the implant surface. Magnesium discs subcutaneously implanted into standard BALB/c mice were immediately infected with Pseudomonas aeruginosa. After one week, tissue adjacent to the implants was subjected to scanning transmission electron microscopic analysis (for a more detailed description see Reference [113]). Bacteria (upper arrow) surrounded by clear areas (lower arrow), indicating the presence of exopolysaccharide matrix material, a typical biofilm component. Reproduced with permission from J. Biomed. Mater. Res.; Published by Wiley 2016. 

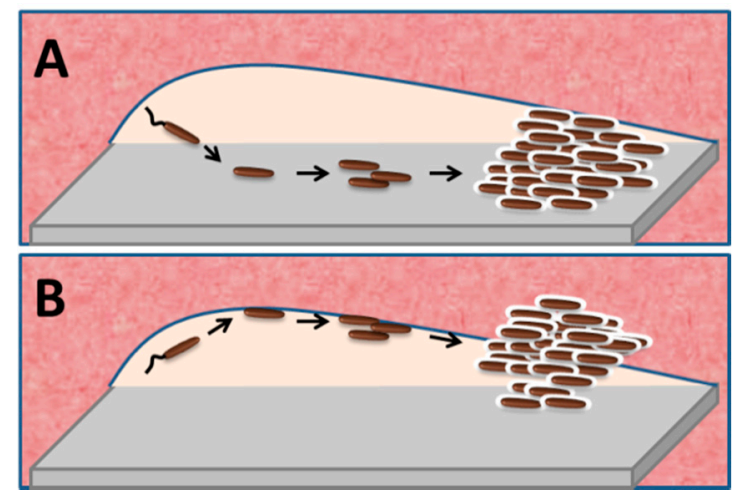

Figure 2. Model proposing tissue infection as initial key step of bacterial implant infections. (A) Conventional model. Consecutive steps of biofilm infections are shown from left to right. Planktonic bacteria (brown) enter the wound-liquid-filled interspace (colorless) between implant (grey) and tissue (pink). As a crucial step towards biofilm formation, bacteria first adhere to the implant surface and form micro-colonies. After reaching a critical density, bacteria switch to the biofilm mode and secrete extracellular matrix compounds. Biofilm features, such as the encapsulation in the matrix, nutrient restriction and slow growth, render the associated bacteria highly resistant to the host immune defenses and to antibiotics. Subsequently, secreted exotoxins and proteases allow bacteria to invade the adjacent host tissue. Alternatively, adhesion of host tissue to the implant acts to protect the implant surface from bacterial attachment and subsequent biofilm formation. Based on the in vitro results, in this scenario magnesium implants would be expected to act bactericidal. (B) Tissue infection model. Under normal circumstances contiguous epithelial cell layers protect living tissue, whereas wounding renders tissue highly susceptible to bacterial infections. After implant insertion the essential initial bacterial attachment occurs primarily at the susceptible injured tissue surface. Bacterial colonies growing on the tissue surface eventually switch to the biofilm mode with analogous outcomes as in the conventional model. While bacterial adhesion to the implant may occur, it plays no essential role for the course of the infection. Adhesion of host tissue to the implant would still be important to antagonize infections but predominantly to protect the wound tissue surface, and not the implant, from bacterial colonization. Despite acting bactericidal upon close contact, the observed enhanced infection susceptibility of magnesium implants is explained by interference of corroding magnesium with host tissue adhesion. Factors that prolong the wound surface exposure to bacteria could be alkaline $\mathrm{pH}$ immediately after implantation, and hydrogen gas evolution or eroding solid corrosion layers thereafter.

\section{Implications for the Design of Antibacterial Implants}

A wide variety of anti-infective implant strategies have been investigated, mostly in vitro [118]. In the light of the proposed tissue invasion model, in order to be efficacious, antibacterial substances would need to be diffusible to reach bacteria in the vicinity of the implant. Therefore, implant nanostructures that act antiadhesive, or passive coatings that act bactericidal upon contact, would not be expected to curb infections in patients. In addition, implant features that affect tissue adhesion play an important, through different, role than previously thought. That is, to primarily prevent bacterial adhesion to the injured tissue rather than to the implant (Table 2). Even though magnesium implants could not curb bacterial infections in mice, clinical data is needed before a final conclusion can be drawn. In addition, several alternative strategies are presently investigated, such as antibiotic-releasing coatings for magnesium-based implants or the addition of antibacterial acting alloy metals like silver, copper, or zinc that release cytotoxic ions [119-125]. The major challenge for such an approach is to maintain the balance of achieving efficacious bactericidal ion concentrations in vivo without damaging the host tissue. 
Table 2. Implant features predicted by the tissue infection model to influence the susceptibility to infections in vivo.

\begin{tabular}{ccc}
\hline Ineffective Coatings & Infection Risks & Favorable Measures \\
\hline $\begin{array}{c}\text { Surfaces that antagonize } \\
\text { bacterial adhesion }\end{array}$ & $\begin{array}{c}\text { Factors that hinder host tissue } \\
\text { adhesion; convex or } \\
\text { microporous surfaces }\end{array}$ & $\begin{array}{c}\text { Surfaces favoring tissue } \\
\text { integration; smooth, flat or } \\
\text { concave forms; }\end{array}$ \\
\hline $\begin{array}{c}\text { Contact-dependent } \\
\text { bactericidal surfaces }\end{array}$ & $\begin{array}{c}\text { Relative movement of } \\
\text { implants versus tissue }\end{array}$ & $\begin{array}{c}\text { Antibacterial } \\
\text { substance-releasing coatings }\end{array}$ \\
\hline
\end{tabular}

\section{Conclusions}

In long-term clinical trials biodegradable polymeric stents were inferior to conventional drug-eluting metal stents, while recently introduced biocorrodible magnesium-based bone screws were without noticeable side effects. However, since in vitro tests and even small animal studies cannot predict the outcome in human patients, long-term clinical confirmation of the expected benefits, with regard to potential risks, are needed. In addition, a novel model for implant infections suggests that host cell adhesion to implants is important to prevent bacterial invasion of the exposed host tissue surface, and not, as previously thought, to prevent bacterial adhesion to the implant. The model predicts that passive antibacterial implant coating strategies would not be efficacious in vivo.

Funding: We acknowledge the financial support by a joint grant to M.I.R. and to S.U. of the German Academic Exchange Service (DAAD), Germany, and the Higher Education Commission of Pakistan (HEC).

Conflicts of Interest: The authors declare that there is no conflict of interest regarding the publication of this paper.

\section{References}

1. Perren, S.M.; Regazzoni, P.; Fernandez, A.A. How to choose between the implant iaterials steel and titanium in orthopedic trauma surgery: Part 2-Biological aspects. Acta Chir. Orthop. Traumatol. Cech. 2017, 84, 85-90. [PubMed]

2. Osman, R.B.; Swain, M.V. A Critical Review of Dental Implant Materials with an Emphasis on Titanium versus Zirconia. Materials (Basel) 2015, 8, 932-958. [CrossRef] [PubMed]

3. Williams, D.F. On the nature of biomaterials. Biomaterials 2009, 30, 5897-5909. [CrossRef] [PubMed]

4. Elias, C.N.; Lima, J.H.C.; Valiev, R.; Meyers, M.A. Biomedical applications of titanium and its alloys. JOM 2008, 60, 46-49. [CrossRef]

5. Sheikh, Z.; Najeeb, S.; Khurshid, Z.; Verma, V.; Rashid, H.; Glogauer, M. Biodegradable Materials for Bone Repair and Tissue Engineering Applications. Materials (Basel) 2015, 8, 5744-5794. [CrossRef] [PubMed]

6. Middleton, J.C.; Tipton, A.J. Synthetic biodegradable polymers as orthopedic devices. Biomaterials 2000, 21, 2335-2346. [CrossRef]

7. Witte, F.; Fischer, J.; Nellesen, J.; Crostack, H.A.; Kaese, V.; Pisch, A.; Beckmann, F.; Windhagen, H. In vitro and in vivo corrosion measurements of magnesium alloys. Biomaterials 2006, 27, 1013-1018. [CrossRef] [PubMed]

8. Martinez Sanchez, A.H.; Luthringer, B.J.; Feyerabend, F.; Willumeit, R. Mg and Mg alloys: How comparable are in vitro and in vivo corrosion rates? A review. Acta Biomater. 2015, 13, 16-31. [CrossRef] [PubMed]

9. Luthringer, B.J.; Feyerabend, F.; Willumeit-Romer, R. Magnesium-based implants: A mini-review. Magnes. Res. 2014, 27, 142-154. [PubMed]

10. Li, H.; Zheng, Y.; Qin, L. Progress of biodegradable metals. Prog. Nat. Sci. 2014, 24, 414-422. [CrossRef]

11. Miller, A.P.; Huff, C.M.; Roubin, G.S. Vascular disease in the older adult. J. Geriatr. Cardiol. JGC 2016, 13, 727-732. [PubMed]

12. Martens, A.; Beckmann, E.; Kaufeld, T.; Umminger, J.; Fleissner, F.; Koigeldiyev, N.; Krueger, H.; Puntigam, J.; Haverich, A.; Shrestha, M. Total aortic arch repair: Risk factor analysis and follow-up in 199 patients. Eur. J. Cardiothorac. Surg. 2016, 50, 940-948. [CrossRef] [PubMed] 
13. Rittersma, S.Z.; de Winter, R.J.; Koch, K.T.; Bax, M.; Schotborgh, C.E.; Mulder, K.J.; Tijssen, J.G.; Piek, J.J. Impact of strut thickness on late luminal loss after coronary artery stent placement. Am. J. Cardiol. 2004, 93, 477-480. [CrossRef] [PubMed]

14. Onche, I.I.; Osagie, O.E.; INuhu, S. Removal of orthopaedic implants: Indications, outcome and economic implications. J. West Afr. Coll. Surg. 2011, 1, 101-112. [PubMed]

15. Levy, J.A.; Podeszwa, D.A.; Lebus, G.; Ho, C.A.; Wimberly, R.L. Acute complications associated with removal of flexible intramedullary femoral rods placed for pediatric femoral shaft fractures. J. Pediatr. Orthop. 2013, 33, 43-47. [CrossRef] [PubMed]

16. Buchanan, K.; Steinvil, A.; Waksman, R. Does the new generation of drug-eluting stents render bare metal stents obsolete? Cardiovasc. Revasc. Med. 2017, 18, 456-461. [CrossRef] [PubMed]

17. Waksman, R. A new generation of drug-eluting stents: Indications and outcomes of bioresorbable vascular scaffolds. Cleve. Clin. J. Med. 2017, 84 (Suppl. S4), e20-e24. [CrossRef] [PubMed]

18. Pleva, L.; Kukla, P.; Hlinomaz, O. Treatment of coronary in-stent restenosis: A systematic review. J. Geriatr. Cardiol. 2018, 15, 173-184. [PubMed]

19. Artang, R.; Dieter, R.S. Analysis of 36 reported cases of late thrombosis in drug-eluting stents placed in coronary arteries. Am. J. Cardiol. 2007, 99, 1039-1043. [CrossRef] [PubMed]

20. Mauri, L.; Hsieh, W.H.; Massaro, J.M.; Ho, K.K.; D’Agostino, R.; Cutlip, D.E. Stent thrombosis in randomized clinical trials of drug-eluting stents. N. Engl. J. Med. 2007, 356, 1020-1029. [CrossRef] [PubMed]

21. Filion, K.B.; Roy, A.M.; Baboushkin, T.; Rinfret, S.; Eisenberg, M.J. Cost-effectiveness of drug-eluting stents including the economic impact of late stent thrombosis. Am. J. Cardiol. 2009, 103, 338-344. [CrossRef] [PubMed]

22. Erne, P.; Schier, M.; Resink, T.J. The road to bioabsorbable stents: Reaching clinical reality? Cardiovasc. Intervent. Radiol. 2006, 29, 11-16. [CrossRef] [PubMed]

23. Tan, L.; Yu, X.; Wan, P.; Yang, K. Biodegradable Materials for Bone Repairs: A Review. J. Mater. Sci. Technol. 2013, 29, 503-513. [CrossRef]

24. Zheng, Y.F.; Gu, X.N.; Witte, F. Biodegradable metals. Mater. Sci. Eng. R Rep. 2014, 77, 1-34. [CrossRef]

25. Waksman, R.; Pakala, R. Biodegradable and bioabsorbable stents. Curr. Pharm. Des. 2010, 16, 4041-4051. [CrossRef] [PubMed]

26. Sumner, D.R. Long-term implant fixation and stress-shielding in total hip replacement. J. Biomech. 2015, 48, 797-800. [CrossRef] [PubMed]

27. Ceonzo, K.; Gaynor, A.; Shaffer, L.; Kojima, K.; Vacanti, C.A.; Stahl, G.L. Polyglycolic acid-induced inflammation: Role of hydrolysis and resulting complement activation. Tissue Eng. 2006, 12, 301-308. [CrossRef] [PubMed]

28. Athanasiou, K.A.; Niederauer, G.G.; Agrawal, C.M. Sterilization, toxicity, biocompatibility and clinical applications of polylactic acid/polyglycolic acid copolymers. Biomaterials 1996, 17, 93-102. [CrossRef]

29. Pierson, D.; Edick, J.; Tauscher, A.; Pokorney, E.; Bowen, P.; Gelbaugh, J.; Stinson, J.; Getty, H.; Lee, C.H.; Drelich, J.; et al. A simplified in vivo approach for evaluating the bioabsorbable behavior of candidate stent materials. J. Biomed. Mater. Res. B Appl. Biomater. 2012, 100, 58-67. [CrossRef] [PubMed]

30. Bowen, P.K.; Drelich, J.; Buxbaum, R.E.; Rajachar, R.M.; Goldman, J. New approaches in evaluating metallic candidates for bioabsorbable stents. Emerg. Mater. Res. 2012, 1, 237-255. [CrossRef]

31. Hermawan, H.; Purnama, A.; Dube, D.; Couet, J.; Mantovani, D. Fe-Mn alloys for metallic biodegradable stents: Degradation and cell viability studies. Acta Biomater. 2010, 6, 1852-1860. [CrossRef] [PubMed]

32. Vojtech, D.; Kubasek, J.; Serak, J.; Novak, P. Mechanical and corrosion properties of newly developed biodegradable Zn-based alloys for bone fixation. Acta Biomater. 2011, 7, 3515-3522. [CrossRef] [PubMed]

33. Yang, H.; Wang, C.; Liu, C.; Chen, H.; Wu, Y.; Han, J.; Jia, Z.; Lin, W.; Zhang, D.; Li, W.; et al. Evolution of the degradation mechanism of pure zinc stent in the one-year study of rabbit abdominal aorta model. Biomaterials 2017, 145, 92-105. [CrossRef] [PubMed]

34. Zhao, D.; Wang, T.; Nahan, K.; Guo, X.; Zhang, Z.; Dong, Z.; Chen, S.; Chou, D.T.; Hong, D.; Kumta, P.N.; et al. In vivo characterization of magnesium alloy biodegradation using electrochemical H2 monitoring, ICP-MS, and XPS. Acta Biomater. 2017, 50, 556-565. [CrossRef] [PubMed]

35. Zhao, D.; Witte, F.; Lu, F.; Wang, J.; Li, J.; Qin, L. Current status on clinical applications of magnesium-based orthopaedic implants: A review from clinical translational perspective. Biomaterials 2017, 112, $287-302$. [CrossRef] [PubMed] 
36. Staiger, M.P.; Pietak, A.M.; Huadmai, J.; Dias, G. Magnesium and its alloys as orthopedic biomaterials: A review. Biomaterials 2006, 27, 1728-1734. [CrossRef] [PubMed]

37. Debieux, P.; Franciozi, C.E.; Lenza, M.; Tamaoki, M.J.; Magnussen, R.A.; Faloppa, F.; Belloti, J.C. Bioabsorbable versus metallic interference screws for graft fixation in anterior cruciate ligament reconstruction. Cochrane Database Syst. Rev. 2016, 7, CD009772. [CrossRef] [PubMed]

38. Seitz, J.M.; Durisin, M.; Goldman, J.; Drelich, J.W. Recent Advances in Biodegradable Metals for Medical Sutures: A Critical Review. Adv. Healthc. Mater. 2015, 4, 1915-1936. [CrossRef] [PubMed]

39. Doppalapudi, S.; Jain, A.; Khan, W.; Domb, A.J. Biodegradable polymers-An overview. Polym. Adv. Technol. 2014, 25, 427-435. [CrossRef]

40. Van der Giessen, W.J.; Lincoff, A.M.; Schwartz, R.S.; van Beusekom, H.M.; Serruys, P.W.; Holmes, D.R., Jr.; Ellis, S.G.; Topol, E.J. Marked inflammatory sequelae to implantation of biodegradable and nonbiodegradable polymers in porcine coronary arteries. Circulation 1996, 94, 1690-1697. [CrossRef] [PubMed]

41. Bunger, C.M.; Grabow, N.; Sternberg, K.; Kroger, C.; Ketner, L.; Schmitz, K.P.; Kreutzer, H.J.; Ince, H.; Nienaber, C.A.; Klar, E.; et al. Sirolimus-eluting biodegradable poly-L-lactide stent for peripheral vascular application: A preliminary study in porcine carotid arteries. J. Surg. Res. 2007, 139, 77-82. [CrossRef] [PubMed]

42. Rizik, D.G.; Hermiller, J.B.; Kereiakes, D.J. Bioresorbable vascular scaffolds for the treatment of coronary artery disease: Clinical outcomes from randomized controlled trials. Catheter. Cardiovasc. Interv. 2016, 88 (Suppl. S1), 21-30. [CrossRef] [PubMed]

43. Ali, Z.A.; Serruys, P.W.; Kimura, T.; Gao, R.; Ellis, S.G.; Kereiakes, D.J.; Onuma, Y.; Simonton, C.; Zhang, Z.; Stone, G.W. 2-year outcomes with the Absorb bioresorbable scaffold for treatment of coronary artery disease: A systematic review and meta-analysis of seven randomised trials with an individual patient data substudy. Lancet 2017, 390, 760-772. [CrossRef]

44. Ali, Z.A.; Gao, R.; Kimura, T.; Onuma, Y.; Kereiakes, D.J.; Ellis, S.G.; Chevalier, B.; Vu, M.T.; Zhang, Z.; Simonton, C.A.; et al. Three-Year Outcomes with the Absorb Bioresorbable Scaffold: Individual-Patient-Data Meta-Analysis from the ABSORB Randomized Trials. Circulation 2018, 137, 464-479. [CrossRef] [PubMed]

45. Peuster, M.; Wohlsein, P.; Brugmann, M.; Ehlerding, M.; Seidler, K.; Fink, C.; Brauer, H.; Fischer, A.; Hausdorf, G. A novel approach to temporary stenting: Degradable cardiovascular stents produced from corrodible metal-results 6-18 months after implantation into New Zealand white rabbits. Heart 2001, 86, 563-569. [CrossRef] [PubMed]

46. Francis, A.; Yang, Y.; Virtanen, S.; Boccaccini, A.R. Iron and iron-based alloys for temporary cardiovascular applications. J. Mater. Sci. Mater. Med. 2015, 26, 138. [CrossRef] [PubMed]

47. Peuster, M.; Hesse, C.; Schloo, T.; Fink, C.; Beerbaum, P.; von Schnakenburg, C. Long-term biocompatibility of a corrodible peripheral iron stent in the porcine descending aorta. Biomaterials 2006, 27, 4955-4962. [CrossRef] [PubMed]

48. Fagali, N.S.; Grillo, C.A.; Puntarulo, S.; Fernandez Lorenzo de Mele, M.A. Cytotoxicity of corrosion products of degradable Fe-based stents: Relevance of $\mathrm{pH}$ and insoluble products. Colloids Surf. B Biointerfaces 2015, 128, 480-488. [CrossRef] [PubMed]

49. Moravej, M.; Purnama, A.; Fiset, M.; Couet, J.; Mantovani, D. Electroformed pure iron as a new biomaterial for degradable stents: In vitro degradation and preliminary cell viability studies. Acta Biomater. 2010, 6, 1843-1851. [CrossRef] [PubMed]

50. Drynda, A.; Hoehn, R.; Peuster, M. Influence of Fe(II) and Fe(III) on the expression of genes related to cholesterol- and fatty acid metabolism in human vascular smooth muscle cells. J. Mater. Sci. Mater. Med. 2010, 21, 1655-1663. [CrossRef] [PubMed]

51. Zhu, S.; Huang, N.; Xu, L.; Zhang, Y.; Liu, H.; Sun, H.; Leng, Y. Biocompatibility of pure iron: In vitro assessment of degradation kinetics and cytotoxicity on endothelial cells. Mater. Sci. Eng. C 2009, 29, 1589-1592. [CrossRef]

52. Mueller, P.P.; May, T.; Perz, A.; Hauser, H.; Peuster, M. Control of smooth muscle cell proliferation by ferrous iron. Biomaterials 2006, 27, 2193-2200. [CrossRef] [PubMed]

53. Kraus, T.; Moszner, F.; Fischerauer, S.; Fiedler, M.; Martinelli, E.; Eichler, J.; Witte, F.; Willbold, E.; Schinhammer, M.; Meischel, M.; et al. Biodegradable Fe-based alloys for use in osteosynthesis: Outcome of an in vivo study after 52 weeks. Acta Biomater. 2014, 10, 3346-3353. [CrossRef] [PubMed] 
54. Mueller, P.P.; Arnold, S.; Badar, M.; Bormann, D.; Bach, F.W.; Drynda, A.; Meyer-Lindenberg, A.; Hauser, H.; Peuster, M. Histological and molecular evaluation of iron as degradable medical implant material in a murine animal model. J. Biomed. Mater. Res. A 2012, 100, 2881-2889. [CrossRef] [PubMed]

55. Voigtlaender, H. [Wandering of foreign bodies. (Grenate fragment in the common bile duct causing jaundice)]. Chirurg 1975, 46, 467-469. [PubMed]

56. Ghislain, P.D. Spontaneous extrusion of hand grenade fragments from the face 60 years after injury. JAMA 2003, 290, 1317-1318. [CrossRef] [PubMed]

57. Gaber, Y. [Grenade splinter injury simulating thrombophlebitis]. Vasa 2003, 32, 40-42. [CrossRef] [PubMed]

58. Mostaed, E.; Sikora-Jasinska, M.; Drelich, J.W.; Vedani, M. Zinc-based alloys for degradable vascular stent applications. Acta Biomater. 2018, 71, 1-23. [CrossRef] [PubMed]

59. Jin, H.; Zhao, S.; Guillory, R.; Bowen, P.K.; Yin, Z.; Griebel, A.; Schaffer, J.; Earley, E.J.; Goldman, J.; Drelich, J.W. Novel high-strength, low-alloys $\mathrm{Zn}-\mathrm{Mg}(<0.1 \mathrm{wt} \% \mathrm{Mg})$ and their arterial biodegradation. Mater. Sci. Eng. C 2018, 84, 67-79. [CrossRef] [PubMed]

60. Bowen, P.K.; Shearier, E.R.; Zhao, S.; Guillory, R.J., 2nd; Zhao, F.; Goldman, J.; Drelich, J.W. Biodegradable Metals for Cardiovascular Stents: From Clinical Concerns to Recent Zn-Alloys. Adv. Healthc. Mater. 2016, 5, 1121-1140. [CrossRef] [PubMed]

61. Bowen, P.K.; Drelich, J.; Goldman, J. Zinc Exhibits Ideal Physiological Corrosion Behavior for Bioabsorbable Stents. Adv. Mater. 2013, 25, 2577-2582. [CrossRef] [PubMed]

62. Bowen, P.K.; Guillory, R.J., 2nd; Shearier, E.R.; Seitz, J.M.; Drelich, J.; Bocks, M.; Zhao, F.; Goldman, J. Metallic zinc exhibits optimal biocompatibility for bioabsorbable endovascular stents. Mater. Sci. Eng. C Mater. Biol. Appl. 2015, 56, 467-472. [CrossRef] [PubMed]

63. Huse, E.C. A New Ligature? Chic. Med. J. Examin. 1878, 37, 171-172.

64. Agarwal, S.; Curtin, J.; Duffy, B.; Jaiswal, S. Biodegradable magnesium alloys for orthopaedic applications: A review on corrosion, biocompatibility and surface modifications. Mater. Sci. Eng. C Mater. Biol. Appl. 2016, 68, 948-963. [CrossRef] [PubMed]

65. Waizy, H.; Seitz, J.-M.; Reifenrath, J.; Weizbauer, A.; Bach, F.-W.; Meyer-Lindenberg, A.; Denkena, B.; Windhagen, H. Biodegradable magnesium implants for orthopedic applications. J. Mater. Sci. 2013, 48, 39-50. [CrossRef]

66. Meagher, P.; O'Cearbhaill, E.D.; Byrne, J.H.; Browne, D.J. Bulk Metallic Glasses for Implantable Medical Devices and Surgical Tools. Adv. Mater. 2016, 28, 5755-5762. [CrossRef] [PubMed]

67. Zberg, B.; Uggowitzer, P.J.; Loffler, J.F. MgZnCa glasses without clinically observable hydrogen evolution for biodegradable implants. Nat. Mater. 2009, 8, 887-891. [CrossRef] [PubMed]

68. Frankel, G.S. Magnesium alloys: Ready for the road. Nat. Mater. 2015, 14, 1189-1190. [CrossRef] [PubMed]

69. Ma, E.; Xu, J. Biodegradable Alloys: The glass window of opportunities. Nat. Mater. 2009, 8, 855-857. [CrossRef] [PubMed]

70. Li, Y.; Liu, L.; Wan, P.; Zhai, Z.; Mao, Z.; Ouyang, Z.; Yu, D.; Sun, Q.; Tan, L.; Ren, L.; et al. Biodegradable $\mathrm{Mg}-\mathrm{Cu}$ alloy implants with antibacterial activity for the treatment of osteomyelitis: In vitro and in vivo evaluations. Biomaterials 2016, 106, 250-263. [CrossRef] [PubMed]

71. Xu, L.; Pan, F.; Yu, G.; Yang, L.; Zhang, E.; Yang, K. In vitro and in vivo evaluation of the surface bioactivity of a calcium phosphate coated magnesium alloy. Biomaterials 2009, 30, 1512-1523. [CrossRef] [PubMed]

72. Wong, H.M.; Yeung, K.W.; Lam, K.O.; Tam, V.; Chu, P.K.; Luk, K.D.; Cheung, K.M. A biodegradable polymer-based coating to control the performance of magnesium alloy orthopaedic implants. Biomaterials 2010, 31, 2084-2096. [CrossRef] [PubMed]

73. Li, X.; Chu, C.L.; Liu, L.; Liu, X.K.; Bai, J.; Guo, C.; Xue, F.; Lin, P.H.; Chu, P.K. Biodegradable poly-lactic acid based-composite reinforced unidirectionally with high-strength magnesium alloy wires. Biomaterials 2015, 49, 135-144. [CrossRef] [PubMed]

74. Thormann, U.; Alt, V.; Heimann, L.; Gasquere, C.; Heiss, C.; Szalay, G.; Franke, J.; Schnettler, R.; Lips, K.S. The Biocompatibility of Degradable Magnesium Interference Screws: An Experimental Study with Sheep. BioMed Res. Int. 2015, 2015, 15. [CrossRef] [PubMed]

75. Hort, N.; Huang, Y.; Fechner, D.; Stormer, M.; Blawert, C.; Witte, F.; Vogt, C.; Drucker, H.; Willumeit, R.; Kainer, K.U.; et al. Magnesium alloys as implant materials-principles of property design for Mg-RE alloys. Acta Biomater. 2010, 6, 1714-1725. [CrossRef] [PubMed] 
76. Kirkland, N.T.; Birbilis, N.; Staiger, M.P. Assessing the corrosion of biodegradable magnesium implants: A critical review of current methodologies and their limitations. Acta Biomater. 2012, 8, 925-936. [CrossRef] [PubMed]

77. Huehnerschulte, T.A.; Angrisani, N.; Rittershaus, D.; Bormann, D.; Windhagen, H.; Meyer-Lindenberg, A. In Vivo Corrosion of Two Novel Magnesium Alloys ZEK100 and AX30 and Their Mechanical Suitability as Biodegradable Implants. Materials (Basel) 2011, 4, 1144-1167. [CrossRef] [PubMed]

78. Krause, A.; von der Höh, N.; Bormann, D.; Krause, C.; Bach, F.-W.; Windhagen, H.; Meyer-Lindenberg, A. Degradation behaviour and mechanical properties of magnesium implants in rabbit tibiae. J. Mater. Sci. 2009, 45, 624. [CrossRef]

79. Zeng, R.; Dietzel, W.; Witte, F.; Hort, N.; Blawert, C. Progress and Challenge for Magnesium Alloys as Biomaterials. Adv. Eng. Mater. 2008, 10, B3-B14. [CrossRef]

80. Kirkland, N.T.; Lespagnol, J.; Birbilis, N.; Staiger, M.P. A survey of bio-corrosion rates of magnesium alloys. Corros. Sci. 2010, 52, 287-291. [CrossRef]

81. Jahnen-Dechent, W.; Ketteler, M. Magnesium basics. Clin. Kidney J. 2012, 5 (Suppl. S1), i3-i14. [CrossRef] [PubMed]

82. De Baaij, J.H.; Hoenderop, J.G.; Bindels, R.J. Magnesium in man: Implications for health and disease. Physiol. Rev. 2015, 95, 1-46. [CrossRef] [PubMed]

83. Han, P.; Cheng, P.; Zhang, S.; Zhao, C.; Ni, J.; Zhang, Y.; Zhong, W.; Hou, P.; Zhang, X.; Zheng, Y.; et al. In vitro and in vivo studies on the degradation of high-purity $\mathrm{Mg}$ (99.99 wt.\%) screw with femoral intracondylar fractured rabbit model. Biomaterials 2015, 64, 57-69. [CrossRef] [PubMed]

84. Badar, M.; Lunsdorf, H.; Evertz, F.; Rahim, M.I.; Glasmacher, B.; Hauser, H.; Mueller, P.P. The formation of an organic coat and the release of corrosion microparticles from metallic magnesium implants. Acta Biomater. 2013, 9, 7580-7589. [CrossRef] [PubMed]

85. Rahim, M.I.; Weizbauer, A.; Evertz, F.; Hoffmann, A.; Rohde, M.; Glasmacher, B.; Windhagen, H.; Gross, G.; Seitz, J.M.; Mueller, P.P. Differential magnesium implant corrosion coat formation and contribution to bone bonding. J. Biomed. Mater. Res. A 2017, 105, 697-709. [CrossRef] [PubMed]

86. Zhang, Y.; Xu, J.; Ruan, Y.C.; Yu, M.K.; O’Laughlin, M.; Wise, H.; Chen, D.; Tian, L.; Shi, D.; Wang, J.; et al. Implant-derived magnesium induces local neuronal production of CGRP to improve bone-fracture healing in rats. Nat. Med. 2016, 22, 1160-1169. [CrossRef] [PubMed]

87. Witte, F.; Kaese, V.; Haferkamp, H.; Switzer, E.; Meyer-Lindenberg, A.; Wirth, C.J.; Windhagen, H. In vivo corrosion of four magnesium alloys and the associated bone response. Biomaterials 2005, 26, 3557-3563. [CrossRef] [PubMed]

88. Kuhlmann, J.; Bartsch, I.; Willbold, E.; Schuchardt, S.; Holz, O.; Hort, N.; Hoche, D.; Heineman, W.R.; Witte, F. Fast escape of hydrogen from gas cavities around corroding magnesium implants. Acta Biomater. 2013, 9 , 8714-8721. [CrossRef] [PubMed]

89. Noviana, D.; Paramitha, D.; Ulum, M.F.; Hermawan, H. The effect of hydrogen gas evolution of magnesium implant on the postimplantation mortality of rats. J. Orthop. Transl. 2016, 5, 9-15. [CrossRef]

90. Chen, Y.; Xu, Z.; Smith, C.; Sankar, J. Recent advances on the development of magnesium alloys for biodegradable implants. Acta Biomater. 2014, 10, 4561-4573. [CrossRef] [PubMed]

91. Grünewald, T.A.; Rennhofer, H.; Hesse, B.; Burghammer, M.; Stanzl-Tschegg, S.E.; Cotte, M.; Löffler, J.F.; Weinberg, A.M.; Lichtenegger, H.C. Magnesium from bioresorbable implants: Distribution and impact on the nano- and mineral structure of bone. Biomaterials 2016, 76, 250-260. [CrossRef] [PubMed]

92. Seitz, J.-M.; Lucas, A.; Kirschner, M. Magnesium-Based Compression Screws: A Novelty in the Clinical Use of Implants. JOM 2016, 68, 1177-1182. [CrossRef]

93. Plaass, C.; von Falck, C.; Ettinger, S.; Sonnow, L.; Calderone, F.; Weizbauer, A.; Reifenrath, J.; Claassen, L.; Waizy, H.; Daniilidis, K.; et al. Bioabsorbable magnesium versus standard titanium compression screws for fixation of distal metatarsal osteotomies-3 year results of a randomized clinical trial. J. Orthop. Sci. 2018, 23, 321-327. [CrossRef] [PubMed]

94. Windhagen, H.; Radtke, K.; Weizbauer, A.; Diekmann, J.; Noll, Y.; Kreimeyer, U.; Schavan, R.; Stukenborg-Colsman, C.; Waizy, H. Biodegradable magnesium-based screw clinically equivalent to titanium screw in hallux valgus surgery: Short term results of the first prospective, randomized, controlled clinical pilot study. Biomed. Eng. Online 2013, 12, 62. [CrossRef] [PubMed] 
95. Ezechieli, M.; Meyer, H.; Lucas, A.; Helmecke, P.; Becher, C.; Calliess, T.; Windhagen, H.; Ettinger, M. Biomechanical Properties of a Novel Biodegradable Magnesium-Based Interference Screw. Orthop. Rev. (Pavia) 2016, 8, 6445. [CrossRef] [PubMed]

96. Biber, R.; Pauser, J.; Brem, M.; Bail, H.J. Bioabsorbable metal screws in traumatology: A promising innovation. Trauma Case Rep. 2017, 8, 11-15. [CrossRef] [PubMed]

97. Ang, H.Y.; Huang, Y.Y.; Lim, S.T.; Wong, P.; Joner, M.; Foin, N. Mechanical behavior of polymer-based vs. metallic-based bioresorbable stents. J. Thorac. Dis. 2017, 9 (Suppl. S9), S923-S934. [CrossRef] [PubMed]

98. Zhao, N.; Watson, N.; Xu, Z.G.; Chen, Y.J.; Waterman, J.; Sankar, J.; Zhu, D.H. In Vitro Biocompatibility and Endothelialization of Novel Magnesium-Rare Earth Alloys for Improved Stent Applications. PLoS ONE 2014, 9, e98674. [CrossRef] [PubMed]

99. Zhu, S.J.; Liu, Q.; Qian, Y.F.; Sun, B.; Wang, L.G.; Wu, J.M.; Guan, S.K. Effect of different processings on mechanical property and corrosion behavior in simulated body fluid of Mg-Zn-Y-Nd alloy for cardiovascular stent application. Front. Mater. Sci. 2014, 8, 256-263. [CrossRef]

100. Mao, L.; Shen, L.; Chen, J.; Zhang, X.; Kwak, M.; Wu, Y.; Fan, R.; Zhang, L.; Pei, J.; Yuan, G.; et al. A promising biodegradable magnesium alloy suitable for clinical vascular stent application. Sci. Rep. 2017, 7, 46343. [CrossRef] [PubMed]

101. Mao, L.; Shen, L.; Chen, J.; Wu, Y.; Kwak, M.; Lu, Y.; Xue, Q.; Pei, J.; Zhang, L.; Yuan, G.; et al. Enhanced bioactivity of Mg-Nd-Zn-Zr alloy achieved with nanoscale MgF2 surface for vascular stent application. ACS Appl. Mater. Interfaces 2015, 7, 5320-5330. [CrossRef] [PubMed]

102. Waksman, R.; Erbel, R.; Di Mario, C.; Bartunek, J.; de Bruyne, B.; Eberli, F.R.; Erne, P.; Haude, M.; Horrigan, M.; Ilsley, C.; et al. Early- and long-term intravascular ultrasound and angiographic findings after bioabsorbable magnesium stent implantation in human coronary arteries. JACC Cardiovasc. Interv. 2009, 2, 312-320. [CrossRef] [PubMed]

103. Erbel, R.; Di Mario, C.; Bartunek, J.; Bonnier, J.; de Bruyne, B.; Eberli, F.R.; Erne, P.; Haude, M.; Heublein, B.; Horrigan, M.; et al. Temporary scaffolding of coronary arteries with bioabsorbable magnesium stents: A prospective, non-randomised multicentre trial. Lancet 2007, 369, 1869-1875. [CrossRef]

104. Rapetto, C.; Leoncini, M. Magmaris: A new generation metallic sirolimus-eluting fully bioresorbable scaffold: Present status and future perspectives. J. Thorac. Dis. 2017, 9 (Suppl. S9), S903-S913. [CrossRef] [PubMed]

105. Haude, M.; Ince, H.; Kische, S.; Abizaid, A.; Tolg, R.; Alves Lemos, P.; Van Mieghem, N.M.; Verheye, S.; von Birgelen, C.; Christiansen, E.H.; et al. Sustained safety and clinical performance of a drug-eluting absorbable metal scaffold up to 24 months: Pooled outcomes of BIOSOLVE-II and BIOSOLVE-III. EuroIntervention 2017, 13, 432-439. [PubMed]

106. Haude, M.; Erbel, R.; Erne, P.; Verheye, S.; Degen, H.; Bose, D.; Vermeersch, P.; Wijnbergen, I.; Weissman, N.; Prati, F.; et al. Safety and performance of the drug-eluting absorbable metal scaffold (DREAMS) in patients with de-novo coronary lesions: 12 month results of the prospective, multicentre, first-in-man BIOSOLVE-I trial. Lancet 2013, 381, 836-844. [CrossRef]

107. Willbold, E.; Weizbauer, A.; Loos, A.; Seitz, J.M.; Angrisani, N.; Windhagen, H.; Reifenrath, J. Magnesium alloys: A stony pathway from intensive research to clinical reality. Different test methods and approval-related considerations. J. Biomed. Mater. Res. A 2017, 105, 329-347. [CrossRef] [PubMed]

108. Arciola, C.R.; Campoccia, D.; Speziale, P.; Montanaro, L.; Costerton, J.W. Biofilm formation in Staphylococcus implant infections. A review of molecular mechanisms and implications for biofilm-resistant materials. Biomaterials 2012, 33, 5967-5982. [CrossRef] [PubMed]

109. Rahim, M.I.; Eifler, R.; Rais, B.; Mueller, P.P. Alkalization is responsible for antibacterial effects of corroding magnesium. J. Biomed. Mater. Res. A 2015, 103, 3526-3532. [CrossRef] [PubMed]

110. Feng, H.; Wang, G.; Jin, W.; Zhang, X.; Huang, Y.; Gao, A.; Wu, H.; Wu, G.; Chu, P.K. Systematic Study of Inherent Antibacterial Properties of Magnesium-based Biomaterials. ACS Appl. Mater. Interfaces 2016, 8, 9662-9673. [CrossRef] [PubMed]

111. Lock, J.Y.; Wyatt, E.; Upadhyayula, S.; Whall, A.; Nunez, V.; Vullev, V.I.; Liu, H. Degradation and antibacterial properties of magnesium alloys in artificial urine for potential resorbable ureteral stent applications. J. Biomed. Mater. Res. A 2014, 102, 781-792. [CrossRef] [PubMed]

112. Robinson, D.A.; Griffith, R.W.; Shechtman, D.; Evans, R.B.; Conzemius, M.G. In vitro antibacterial properties of magnesium metal against Escherichia coli, Pseudomonas aeruginosa and Staphylococcus aureus. Acta Biomater. 2010, 6, 1869-1877. [CrossRef] [PubMed] 
113. Rahim, M.I.; Rohde, M.; Rais, B.; Seitz, J.-M.; Mueller, P.P. Susceptibility of metallic magnesium implants to bacterial biofilm infections. J. Biomed. Mater. Res. A 2016, 104, 1489-1499. [CrossRef] [PubMed]

114. Hou, P.; Zhao, C.; Cheng, P.; Wu, H.; Ni, J.; Zhang, S.; Lou, T.; Wang, C.; Han, P.; Zhang, X.; et al. Reduced antibacterial property of metallic magnesium in vivo. Biomed. Mater. 2016, 12, 015010. [CrossRef] [PubMed]

115. Gristina, A.G.; Naylor, P.; Myrvik, Q. Infections from biomaterials and implants: A race for the surface. Med. Prog. Technol. 1988, 14, 205-224. [PubMed]

116. Church, D.; Elsayed, S.; Reid, O.; Winston, B.; Lindsay, R. Burn wound infections. Clin. Microbiol. Rev. 2006, 19, 403-434. [CrossRef] [PubMed]

117. Stern, G.A. Pseudomonas keratitis and contact lens wear: The lens/eye is at fault. Cornea 1990, 9 (Suppl. S1), S39-S40. [CrossRef] [PubMed]

118. Qin, S.; Xu, K.; Nie, B.; Ji, F.; Zhang, H. Approaches based on passive and active antibacterial coating on titanium to achieve antibacterial activity. J. Biomed. Mater. Res. A 2018. [CrossRef] [PubMed]

119. Liu, Z.D.; Schade, R.; Luthringer, B.; Hort, N.; Rothe, H.; Muller, S.; Liefeith, K.; Willumeit-Romer, R.; Feyerabend, F. Influence of the Microstructure and Silver Content on Degradation, Cytocompatibility, and Antibacterial Properties of Magnesium-Silver Alloys In Vitro. Oxid. Med. Cell. Longev. 2017, 2017, 8091265. [CrossRef] [PubMed]

120. Zhang, X.D.; Yi, J.H.; Zhao, G.W.; Huang, L.L.; Yan, G.J.; Chen, Y.S.; Liu, P. Layer-by-layer assembly of silver nanoparticles embedded polyelectrolyte multilayer on magnesium alloy with enhanced antibacterial property. Surf. Coat. Technol. 2016, 286, 103-112. [CrossRef]

121. Yu, W.L.; Chen, D.Y.; Ding, Z.Y.; Qiu, M.L.; Zhang, Z.W.; Shen, J.; Zhang, X.N.; Zhang, S.X.; He, Y.H.; Shi, Z.M. Synergistic effect of a biodegradable $\mathrm{Mg}$-Zn alloy on osteogenic activity and anti-biofilm ability: An in vitro and in vivo study. RSC Adv. 2016, 6, 45219-45230. [CrossRef]

122. Zhao, C.; Hou, P.; Ni, J.; Han, P.; Chai, Y.; Zhang, X. Ag-Incorporated FHA Coating on Pure Mg: Degradation and in Vitro Antibacterial Properties. ACS Appl. Mater. Interfaces 2016, 8, 5093-5103. [CrossRef] [PubMed]

123. Qin, H.; Zhao, Y.; An, Z.; Cheng, M.; Wang, Q.; Cheng, T.; Wang, Q.; Wang, J.; Jiang, Y.; Zhang, X.; et al. Enhanced antibacterial properties, biocompatibility, and corrosion resistance of degradable $\mathrm{Mg}-\mathrm{Nd}-\mathrm{Zn}-\mathrm{Zr}$ alloy. Biomaterials 2015, 53, 211-220. [CrossRef] [PubMed]

124. Tie, D.; Feyerabend, F.; Hort, N.; Hoeche, D.; Kainer, K.U.; Willumeit, R.; Mueller, W.D. In vitro mechanical and corrosion properties of biodegradable Mg-Ag alloys. Mater. Corros. 2014, 65, 569-576. [CrossRef]

125. Zhang, X.B.; Ba, Z.X.; Wang, Z.Z.; He, X.C.; Shen, C.; Wang, Q. Influence of silver addition on microstructure and corrosion behavior of Mg-Nd-Zn-Zr alloys for biomedical application. Mater. Lett. 2013, 100, 188-191. [CrossRef]

(C) 2018 by the authors. Licensee MDPI, Basel, Switzerland. This article is an open access article distributed under the terms and conditions of the Creative Commons Attribution (CC BY) license (http://creativecommons.org/licenses/by/4.0/). 